Niepełnosprawność. Dyskursy pedagogiki specjalnej

Anna Wojnarska, Renata Zubrzycka

Instytut Pedagogiki UMCS Lublin

\title{
Poczucie osamotnienia osób niepełnosprawnych intelektualnie
}

\section{The feeling of loneliness at people with intellectual disabilities}

Presented study contains a review of Polish and global research focusing on the feeling of loneliness in intellectually disabled (ID) people. Research conducted in various ID groups: younger and older people, boys and girls, students in special and integrated classes, people living in special institutions and family homes has been carefully analyzed. The results of the analysis indicate the significance of these variables for the intensity of the feeling of loneliness in ID students and reveal a strong dependence between the feeling of loneliness and depression. The study provided directions for therapy concerning decrease of loneliness and depression in the intellectually disabled group.

Słowa kluczowe: niepełnosprawność intelektualna (NI), poczucie osamotnienia, inkluzja społeczna, depresja

Keywords: intellectual disability, feeling of loneliness, social inclusion, depression

\section{Wprowadzenie}

Prezentowany artykuł zawiera przegląd badań polskich i światowych na temat poczucia osamotnienia osób niepełnosprawnych intelektualnie. Dokonano analizy badań przeprowadzanych na różnych grupach niepełnosprawnych intelektualnie: osób w różnym wieku, dziewcząt i chłopców, uczniów klas integracyjnych $i$ klas specjalnych, przebywających w instytucjach i domach rodzinnych. Rezultatem tej analizy jest zwrócenie uwagi na znaczenie tych zmiennych dla nasilenia poczucia osamotnienia NI oraz stwierdzenie istnienia dość silnego związku pomiędzy poczuciem osamotnienia a depresją NI. Badania pozwoliły na nakreślenie kierunku oddziaływań terapeutycznych dotyczących łagodzenia nasilenia poczucia osamotnienia i depresji u NI. 


\section{Konceptualizacja pojęcia samotność}

Człowiek - jako istota społeczna - zaspokaja swoje ważne życiowo potrzeby w interakcjach z innymi ludźmi, dlatego też samotność spostrzegana jest jako sytuacja negatywna i jest kojarzona ze stanami frustracji, którym towarzyszą negatywne emocje, takie jak: smutek, gniew, lęk, poczucie nieszczęścia. Pomimo dość jednoznacznego rozumienia pojęcia samotności w znaczeniu potocznym, nie jest ono równie jednoznacznie wyjaśniane na gruncie nauki. Należy uznać je za interdyscyplinarny fenomen posiadający złożoną strukturę. Próby opisania i analizy tego fenomenu znajdujemy głównie na gruncie antropologiczno-filozoficznym, gdzie jest uznawane za zjawisko równie ważne dla człowieka, jak zaspokojenie potrzeb oraz w podejściu socjologiczno-psychologicznym jako przeżycie towarzyszące sytuacji izolacji społecznej (Dołęga 2003).

Osamotnienie jest stanem, w którym człowiek nie ma szansy zaspokojenia swoich potrzeb psychicznych (miłości, bezpieczeństwa, przynależności, uznania) $\mathrm{w}$ relacjach interpersonalnych i jest świadomy tej niemożności, co wywołuje u niego poczucie stresu. Pomimo że w literaturze pojęcia samotności i osamotnienia są często stosowane zamiennie, to wielu badaczy dokonuje ich zróżnicowania. J. Szczepański (1978, za: Kościelak 1996) zwraca uwagę na fakt, że samotność z wyboru może mieć bardzo korzystny wpływ na rozwój osobowy, podczas gdy poczucie osamotnienia jest zawsze zjawiskiem negatywnym. Poczucie osamotnienia odzwierciedla rozbieżność pomiędzy oczekiwaniami dotyczącymi relacji społecznych a ich rzeczywistą realizacją (Asher i in. 1990, za: Heiman, Margalit 1998). Posiada wymiar subiektywny jako poczucie osamotnienia i wymiar obiektywny jako realny brak kontaktów społecznych, czyli rzeczywista izolacja społeczna (Rembowski 1989). Dodatkowo osamotnienie może być interpretowane jako osamotnienie poznawcze, gdy człowiek spostrzega i interpretuje sytuację w określony sposób lub jako osamotnienie emocjonalne, gdy pomimo licznych kontaktów czuje się samotny. Ten rodzaj samotności został opisany w literaturze psychologicznej jako samotność w tłumie (Riesman, Glazer, Denney 1996) i wynika z nadmiaru powierzchownych kontaktów, które zamiast realnego wsparcia społecznego niosą ze sobą poczucie naruszenia intymności - potrzeby towarzyszącej człowiekowi od chwili narodzenia (Weiss 1973, za: Rembowski 1989, s. 4).

Reprezentanci podejścia poznawczego postulują rozróżnienie samotności ze względu na intensywność przeżywania i czas trwania na samotność: chwilową, okresową (krótkotrwałą) oraz chroniczną (Perlman, Peplau 1981, za: Rembowski 1991). Ze względu na relacyjność odniesień, zawartość treściową i orientację czasową można wyróżnić trzy aspekty poczucia osamotnienia: emocjonalne, społeczne i egzystencjalne (Dołęga 1997, 2003). Osamotnienie emocjonalne - ro- 
zumiane tak jak wspomniano powyżej - wiąże się z negatywną oceną własnej osoby w relacjach społecznych i towarzyszącymi negatywnymi stanami emocjonalnymi oraz z różnego rodzaju zaburzeniami funkcjonowania psychospołecznego wyrażającego się poczuciem nieszczęścia, niską samooceną, przekonaniem o własnej nieatrakcyjności (Rembowski 1989, s. 7). Natomiast osamotnienie społeczne charakteryzuje sytuacje, w których człowiek bez powodzenia dąży do kontaktów społecznych, co wynika z braku możliwości nawiązania takich relacji i w związku z tym ma poczucie izolacji i marginalizacji. Ten rodzaj samotności jest nazywany fizycznym lub obiektywnym (Gajda 1997), a dość bliskim mu znaczeniowo jest - wspomniane wcześniej - pojęcie percepcji samotności.

Samotność egzystencjalną charakteryzuje stan braku identyfikacji z normami, celami życiowymi i rolami społecznymi, co powoduje dezintegrację osobowościową. Często ten stan jest określany jako alienacja lub samoalienacja i charakteryzuje się „wewnętrzną pustką, poczuciem nicości, utratą pewnych aspektów tożsamości, niezdolnością do rozumienia siebie i świata, braku poczucia sensu życia, poczuciu beznadziejności i utraty kontroli nad własnym życiem oraz przekonaniem o bezbronności jednostki wobec okoliczności życia" (Dołęga 2003, s. 25). Takie przekonania decydują o ukształtowaniu się światopoglądu nacechowanego nihilizmem, cynizmem i pesymizmem. Według M. Seemana (za: Kościelak 1996, s. 181) alienacja posiada pięć wymiarów: poczucie bezsensu, bezsilności, anomii, izolacji i samowyobcowania. Alienacja prowadzi do oderwania się jednostki od kontekstu kulturowego i społecznego często przybierając formę buntu wobec systemu.

Z. Dołęga (1997, s. 445), analizując fenomen samotności w aspekcie rozwojowym, zwróciła uwagę na dodatkowe dymensje, pojawiające się w wypowiedziach młodych dorosłych, którzy wyodrębnili samotność: fizyczną i psychiczną, chcianą i niechcianą oraz zewnętrzną i wewnętrzną. Szczególne znaczenie badani przypisywali ostatniemu rodzajowi samotności wyrażającemu się problemami w relacji z samym sobą i trudnościami w kształtowaniu się własnej tożsamości. Warto jednak podkreślić, że począwszy od okresu adolescencji młodzi ludzie zaczynają dostrzegać pozytywne znaczenie samotności dla kształtowania dojrzałej osobowości. Dostrzegają oni, że sytuacje zamierzonej samotności pozwalają nawiązać kontakt z własnymi uczuciami, zdefiniować relacje z innymi ludźmi, ograniczyć zbędne bodźce.

Samotność z wyboru może charakteryzować jednostki kreatywne, dla których chwile odosobnienia są okazją do twórczej pracy artystycznej lub naukowej. Najczęściej tego typu samotność ma charakter okresowy, może być w każdej chwili przerwana i nie wiąże się z przykrymi emocjami. Afirmację samotności można odnaleźć również w praktykach medytacyjnych pozwalających uzyskać spokój ducha i umysłu oraz wejść na wyższy poziom rozwoju osobowości. Ten ro- 
dzaj samotności może być określony mianem konstruktywnej, w przeciwieństwie do samotności niekonstruktywnej, dezintegrującej, która prowadzi do stanów psychotycznych (Albisetti 1999; Rembowski 1992).

R. Grotesky (1965, za: Rembowski 1992, s. 31-32) wyróżnia cztery typy samotności, które mają różne znaczenie w rozwoju osobowym człowieka:

- samotność fizyczną polegającą na przestrzennym i/lub czasowym oddzieleniu od dotychczasowego środowiska, np. związaną z wyjazdem do pracy,

- samotność wynikającą z odrzucenia przez środowisko, wyłączenie ze społeczności, do której człowiek chciałby należeć, towarzyszy jej stan alienacji,

- stan izolacji wynikający z zewnętrznych warunków, np. pobyt w szpitalu, osadzenie w zakładzie karnym,

- osamotnienie polega na wyborze życia i pracy w pojedynkę, czemu towarzyszą bardziej spokój i filozoficzna refleksja niż stan frustracji.

Próby kategoryzacji rodzajów samotności wskazują na złożoność zjawiska, a także jego zróżnicowane znaczenie w życiu człowieka.

\section{Metody badania poczucia osamotnienia osób NI}

Badanie poczucia osamotnienia w grupie osób z NI za pomocą kwestionariuszy przeznaczonych do tego celu napotyka na liczne trudności wynikające z możliwości psychofizycznych NI. Zaburzenia koncentracji uwagi, pamięci, rozwoju językowego oraz myślenia powodują, że informacje zebrane w tej grupie są mniej diagnostyczne niż w grupie osób bez NI. Z tego powodu powinno się stosować narzędzia krótsze zawierające itemy sformułowane w prosty sposób. R.J. Stancliffe i in. (2014) zwrócili uwagę, że problemem może być zrozumienie przez NI takich pojęć, jak: określenia częstotliwości „nigdy”, ,"często”, „rzadko”. B.A. Lehman i in. (2013) zauważają, że osoby z NI mają problem z generalizowaniem swoich sądów i opinii, dlatego często odpowiadają jak jest $\mathrm{w}$ chwili obecnej, a nie jak jest często lub zwykle. W przypadku jednego z najbardziej popularnych kwestionariusz UCLALS wskaźnik odpowiedzi wyniósł zaledwie 25,0\%. K.R. McVilly i in. (2006), badając dorosłych z NI za pomocą Skali Samotności (Loneliness Scale Asher i Wheeler 1985), dokonali kilku istotnych modyfikacji. Zmieniono brzmienie itemów z drugiej na pierwszą osobę zamieniając np. pytanie "Czy masz przyjaciół w szkole" na "Mam przyjaciół w szkole”. Zwiększono zakres skalowania z trzech do pięciu punktów oraz dodatkowo zastosowano jako pomoc do poszczególnych itemów karty ilustrujące treść. Dodatkowo osoby badające udzielały pomocy $\mathrm{w}$ etapie czytania pytań, a nawet zaznaczania odpowiedzi na arkuszach testowych. Podobne zmiany w procedurze badania wprowadził R. Kościelak (1996), który badając grupę NI zastosował procedurę indywidualną, a w grupie porów- 
nawczej procedurę badań grupowych. Dobrym rozwiązaniem wydaje się także zastosowanie częściowo ustrukturyzowanego wywiadu jako metody uzupełniającej (McVilly i in. 2006; Papoutsaki i in. 2013) lub jako metody podstawowej (Mason i in. 2013). T. Heiman (2001), badając skłonności depresyjne i poczucie osamotnienia uczniów szkół specjalnych i ogólnodostępnych, również stosował techniki modyfikowane na potrzeby tej grupy oraz adaptowane do warunków kulturowych Izraela.

Warto zwrócić uwagę na fakt, że badanymi osobami NI były głównie osoby NI w stopniu lekkim, rzadko w stopniu umiarkowanym (Broer i in. 2011). Ponadto kilka badań oparto na modelu badań podłużnych, w których analizowano zmiany poczucia osamotnienia na przestrzeni kilku lat (Lehmann $\mathrm{i}$ in. 2013).

\section{Przyczyny i konsekwencje poczucia osamotnienia NI}

Problem poczucia osamotnienia osób NI stosunkowo rzadko był przedmiotem badań polskich psychologów i pedagogów, choć wydaje się, że jest to zagadnienie bardzo ważne z punktu widzenia praktyki rehabilitacji. Kierunki poszukiwań koncentrowały się na przyczynach pojawiania się poczucia osamotnienia (osobowych i społecznych) oraz konsekwencjach przeżywania tego stanu (depresji, wrogości, agresji). Okazuje się, że dzieci z rodzin o wysokim wskaźniku spójności charakteryzują się niskim poziomem poczucia samotności, są silne psychiczne i manifestują pozytywne oczekiwania wobec przyszłości (Sharabi, Levi, Margalit 2012). Warto podkreślić, że dzieci i młodzież NI uzyskują niski status socjometryczny w grupie rówieśników, najczęściej nie ma bliskich przyjaciół i jest przez nich odrzucana (Papoutsaki, Gena, Kalya 2013). Tymczasem przyjaźń stanowi podstawowe uwarunkowanie dobrego samopoczucia i pełni rolę chroniącą przed zaburzeniami psychicznymi i fizycznymi, ponieważ $\mathrm{w}$ bliskich relacjach uruchamiane są pozytywne emocje, co deklarują również osoby z NI (Mason i in. 2013).

R. Kościelak (1996) przeprowadził badania 100 osób NI i 100 bez NI w wieku 15-17 lat za pomocą Skali SAGS (The Syracuse - Amsterdam - Groningen Sociometric Scale) w adaptacji J. Rembowskiego (1992) oraz ankiety własnej konstrukcji, którą można uznać za podstawę częściowo ustrukturowanego wywiadu. Na podstawie wyników ankiety stwierdzono, że młodzież NI rozumie osamotnienie w sposób bardzo podobny do młodzieży bez NI, choć udzielane odpowiedzi NI były uboższe językowo i wymagały większego wysiłku ze strony badanych. Wyniki Skali SAGS pozwoliły stwierdzić, że ponad połowa NI przeżywa osamotnienie w relacjach z osobami znaczącymi, głównie rodzicami i rówieśnikami. Dziewczęta NI odczuwają osamotnienie znacznie intensywniej niż NI chłopcy, przy 
czym zdaniem R. Kościelaka (1996, s. 194) wiąże się to z bardzo złą sytuacją rodzinną dziewczynek. Ponad $40 \%$ z nich wychowywało się w rodzinach niepełnych. w rodzinach zastępczych, a jeśli nawet były to rodziny pełne, to obciążone patologiami społecznymi w postaci alkoholizmu, niewydolności wychowawczej i chorób psychicznych rodziców. M. Gawęcka i M. Szczepska-Pustkowska (za: Wasilewska 2010) podkreślają, że poczucie osamotnienia dziecka wynika z zaburzenia więzi emocjonalnej z rodzicami, postaw odrzucenia i obojętności oraz braku wypełniania podstawowych funkcji rodzicielskich. Poglądy te są w pełni zbieżne z koncepcją M. Łopatkowej (1993). Jeszcze jedną różnicą jakościową ujawnioną $w$ badaniach R. Kościelaka była odmienna atrybucja przyczyn poczucia osamotnienia - młodzież NI upatrywała ich w czynnikach zewnętrznych, podczas gdy młodzież bez NI w samym człowieku i jego decyzjach.

Analiza literatury przedmiotu ujawnia, że najczęściej poszukiwano zależności pomiędzy depresją a poczuciem osamotnienia. W licznych badaniach (Hojat 1982; Solano, Batten, Parish 1980, 1982, za: Rembowski 1989) wykazano, że prawdopodobnie obydwa zjawiska są ze sobą ściśle powiązane. Osoby odczuwające osamotnienie częściej manifestowały zaburzenia depresyjne, nasilony neurotyzm i psychotyzm, a także wrogość, niepokój, trudności komunikowania się (Mijusković 1983, 1985, za: Rembowski 1989). Jednak K. Rook (1984) uważa, że istnieją zasadnicze różnice pomiędzy depresją a poczuciem osamotnienia, ponieważ depresja wiąże się z ogólnie obniżonym nastrojem i brakiem satysfakcji we wszystkich obszarach funkcjonowania, podczas gdy samotność zazwyczaj ogranicza się tylko do kontaktów interpersonalnych, dlatego poczucie osamotnienia i depresja mogą być doświadczane niezależnie. W przypadku depresji odczuwanie osamotnienia stanowi jeden z podstawowych objawów osiowych, dlatego występowanie tego typu zależności jest zgodne z oczekiwaniami. W przypadku osób NI stwierdza się podwyższone ryzyko występowania zaburzeń nastroju w porównaniu z ogólną populacją, co jest zdeterminowane cechami psychofizycznymi tych osób oraz kontekstem społeczno-kulturowym NI (Heiman 2001).

J. Rola $(2004,2005)$ zajął się problemem związku pomiędzy poczuciem osamotnienia a depresyjnością dzieci NI. W tym celu przebadał Skalą SAGS oraz Skalą Depresyjności M. Kovacs 70 dzieci w wieku 12-14 lat, z czego połowę $(\mathrm{n}=35)$ stanowiły dzieci z NI, zaś pozostałe 35 dzieci charakteryzowało się prawidłowym rozwojem intelektualnym. Porównania wyników między grupami ujawniły, że dzieci NI częściej niż ich sprawni intelektualnie rówieśnicy czują się osamotnione, przy czym chłopcy NI intensywniej niż dziewczynki NI przeżywali poczucie osamotnienia, co może wynikać $\mathrm{z}$ większej roli grup rówieśniczych $\mathrm{w}$ socjalizacji chłopców. Pojawiła się również dość silna korelacja między poczuciem osamotnienia a depresyjnością dzieci $(\mathrm{r}=051, \mathrm{p}<0,01)$. 
W przypadku osób NI pojawiają się dodatkowe uwarunkowania nasilające odczucie izolacji społecznej. Dzieci NI manifestują więcej zaburzeń w zachowaniu w postaci agresji, wycofania się i fobii, które wynikają z wysokiego poziomu lęku, impulsywności, niskiej samooceny i tolerancji na frustrację. Deficyty w sferze poznawczej, takie jak: trudności w percepcji i interpretacji sygnałów społecznych, zaburzenia koncentracji uwagi, pamięci i opóźniony rozwój mowy utrudniają nawiązywanie kontaktów społecznych (Papoutsaki, Gena, Kalya 2013). Cechy indywidualne powodują, że osoby NI doświadczają raczej ograniczonej akceptacji ze strony innych osób, a dzieci są często odrzucane przez rówieśników. Ze względu na swoje możliwości psychofizyczne osoby NI mają mniej możliwości rozwijania bliskich kontaktów i wchodzenia w różnorodne interakcje społeczne (Mason i in. 2013).

A. Giryński (1998) zbadał 300 osób skalą SAGS i Skalą Rascha, w tym 150 NI w stopniu lekkim i 150 sprawnych intelektualnie. Średnia wieku wynosiła 16,7. Dokonane porównania wyników między grupami pozwoliły stwierdzić, że osoby NI bardziej odczuwały osamotnienie w zakresie wszystkich podskal SAGS; stosunków z rówieśnikami, rodzicami i innymi osobami znaczącymi. Również wyniki Skali Rascha wykazały istotne różnice na niekorzyść NI w obszarze izolacji społecznej, deprywacji potrzeby kontaktu społecznego, sytuacyjne poczucie odrzucenia i poczucie utraty grupy towarzyskiej. Badania ujawniły również, że poczucie osamotnienia koreluje $\mathrm{z}$ nieprawidłowym wypełnianiem ról społecznych przez NI. A. Giryński (2004) w dalszych eksploracjach zajął się problemem związku pomiędzy postawami rodzicielskimi a poczuciem osamotnienia. W tym celu przebadał 100 dziewcząt NI i 100 chłopców NI w wieku 13-15 lat oraz ich matek Skalą SAGS i kwestionariuszem postaw rodzicielskich M. Ziemskiej. Analiza korelacyjna wykazała istnienie, zróżnicowanych co do siły, zależności pomiędzy postawami rodzicielskimi, takimi jak: bezradność, nadmierne ochranianie i nadmierny dystans a poczucie osamotnienia we wszystkich aspektach stosunków społecznych (rówieśnicy, rodzice, inne osoby znaczące).

T. Heiman i M. Margalit (1998) zbadali 575 uczniów z lekką NI w wieku 11-16 lat uczących się w szkołach specjalnych i w systemie integracyjnym oraz grupę porównawczą młodzieży bez NI, za pomocą trzech technik diagnozujących samotność, depresję, umiejętności społeczne i percepcję funkcjonowania osób badanych przez rówieśników. We wszystkich analizowanych aspektach grupy NI manifestowały bardziej nasilone poczucie osamotnienia, depresji niż grupa porównawcza, natomiast grupa uczniów NI ze szkół integracyjnych prezentowała najwyższy poziom osamotnienia i najwyższy poziom umiejętności społecznych, natomiast uczniowie NI ze szkół specjalnych najwyższy poziom depresji. Analiza wariancji wykazała różnice między grupami, między dziewczętami i chłopcami oraz młodszymi i starszymi uczniami, nie wykazała jednak różnic ze względu na 
interakcyjny wpływ tych zmiennych na zmienne zależne. Analiza regresji wielokrotnej ujawniła predykcyjne znaczenie zmiennej depresja i akceptacja rówieśników w grupie uczniów bez NI oraz uczniów NI w systemie integracyjnym, podczas gdy w odniesieniu do uczniów NI ze szkół specjalnych takie znaczenie miała depresja i umiejętności społeczne. Zgodnie z oczekiwaniami negatywne korelacje zostały wykryte pomiędzy poczuciem osamotnienia a umiejętnościami społecznymi oraz depresją a umiejętnościami społecznymi. Badania ujawniły nasilanie się negatywnej percepcji poczucia samotności oraz intensywności doznań depresyjnych wśród młodzieży NI w wieku dorastania, podczas gdy zgodnie $\mathrm{z}$ badaniami Z. Dołęgi (1997) adolescenci bez problemów rozwojowych zaczynają pozytywnie wartościować samotność. Potwierdziła się również tendencja typowa dla ogólnej populacji, że to dziewczęta ujawniają wyższy poziom samotności i depresji, co może wynikać z ich większej niż u chłopców wrażliwości i podatności na zranienia. Okazało się, że system nauczania NI ma również znaczenie w kreowaniu negatywnych cech osobowych, przy czym nie uzyskano jednoznacznej odpowiedzi, który system jest bardziej pożądany. System integracji wydaje się nasilać poczucie osamotnienia, ale jednocześnie poprawia umiejętności społeczne (Heiman, Margalit 1998, s. 161).

W kolejnych eksploracjach T. Heiman (2001) ponownie porównywał uczniów NI w szkołach specjalnych i ogólnodostępnych otrzymując nieco inne rezultaty. Tym razem to właśnie uczniowie szkół specjalnych prezentowali wyższy poziom poczucia samotności i depresji (podobnie jak w poprzednich badaniach) niż uczniowie w szkołach masowych, co prawdopodobnie wynika z bardziej różnorodnych i bogatszych kontaktów społecznych tych ostatnich. Wieloczynnikowa analiza wariancji ujawniła, że dziewczynki w porównaniu z chłopcami manifestują bardziej nasilone poczucie osamotnienia i depresji, natomiast chłopcy, w opinii oceniających ich nauczycieli, wykazują wyższy poziom kompetencji szkolnych, ale mają bardziej rozproszoną uwagę i mniejszą niezależność. Uczniowie NI w szkołach ogólnodostępnych według własnej oceny prezentowali niższy poziom umiejętności społecznych niż ich koledzy ze szkól specjalnych i tak samo oceniani byli przez nauczycieli. Prawdopodobnie wynikało to z porównywania ich umiejętności społecznych z uczniami bez NI, podczas gdy w szkołach specjalnych porównania dotyczyły tylko uczniów z NI.

K. Papoutsaki, A. Gena i E. Kalyva (2013) przeprowadziły badania 154 dzieci i młodzieży NI (II= 50-75) w wieku 7-14 lat ze szkól specjalnych w Grecji. Zastosowano 9-pytaniowy kwestionariusz oraz $\mathrm{w}$ połowie ustrukturowany wywiad dotyczący tego, jak dzieci spostrzegają swoją samotność oraz jak sobie z tą samotnością radzą. Ponad połowa dzieci $(51,9 \%)$ nie deklarowała, że odczuwa osamotnienie. Większość dzieci miała przyjaciól wśród sąsiadów i rodzeństwa, natomiast nie miała ich w szkole i wśród dzieci przyjaciół rodziców. Dzieci przede wszyst- 
kim spostrzegały swoje problemy $\mathrm{w}$ budowaniu bliskich relacji z rówieśnikami, w tym, że miały mało zróżnicowanych kontaktów, co wzbudzało w nich smutek i/lub gniew. Strategiami mającymi im pomóc w poradzeniu sobie z tymi przykrymi doznaniami było wycofywanie się ze społecznych interakcji, preferowanie samotnego spędzania czasu, ale również aktywne poszukiwanie przyjaciół albo odreagowujące zachowania agresywne. Okazało się, że chłopcy w mniejszym stopniu niż dziewczynki czują się samotni. Ponadto dzieci z małych miejscowości, w których lokalna społeczność jest bardziej zintegrowana, w mniejszym stopniu niż dzieci ze stolicy odczuwają osamotnienie.

Podobną procedurę ilościowo-jakościową zastosowali K.R. McVilly i in. (2006), którzy badali spostrzeganie przez dorosłych NI (w wieku 16-57 lat) samotności i wyobrażenie cech dobrego przyjaciela. Obydwie strategie ujawniły duży niedosyt bliskich kontaktów osób NI. Metoda jakościowa, oparta na częściowo strukturalizowanym wywiadzie, pozwoliła scharakteryzować jak spostrzegana jest rola przyjaciela w życiu osoby niepełnosprawnej. Wyniki były zgodne z oczekiwaniami, ponieważ grupa ta nie różniła się od ogólnej populacji w zakresie stereotypowych wyobrażeń na temat przyjaźni. Natomiast w zakresie realnych doświadczeń w tym zakresie NI deklarowali zbyt mało okazji do kontaktów, kontakty ograniczone tylko do najbliższej rodziny lub rezydentów instytucji i personelu. Młode osoby NI wyrażały także pragnienie posiadania osoby, która nie tylko będzie ich przyjacielem, ale także partnerem życiowym. Interesujące jest, że u starzejących się osób z NI poczucie osamotnienia nie nasila się, ale często jest mniejsze niż u młodszych NI. B.A. Lehman i in. (2013) stwierdzają, że osoby NI w zaawansowanym wieku, pomimo mniejszej autonomii i stale pogarszającego się zdrowia, potrafią sobie radzić lepiej i odczuwają większą satysfakcję z życia niż NI młodsi. Deklarują również zadowolenie z niewielkich, ale stabilnych sieci społecznego wsparcia, które jest udzielane głownie przez członków rodziny.

Poczucie osamotnienia jest ściśle powiązane ze wsparciem społecznym, przy czym należy rozróżnić wsparcie spostrzegane i faktycznie otrzymywane. Y. Lunsky i B.A. Benson (2001) przeprowadziły badania dorosłych NI i ujawniły, że trudności NI w trafnym interpretowaniu sytuacji społecznych powodują błędne odkodowywanie sygnałów świadczących o wsparciu. Osoby te miały oceniać przedstawione w krótkich filmach ilustrujących sytuacje wsparcia pozytywnego, ambiwalentne i takie, gdy tego wsparcia nie było. Okazało się, że NI przeceniali pozytywnie prezentowany materiał wskazując na istnienie pozytywnej relacji w sytuacjach ambiwalentnych i negatywnych. Badaczki ujawniły również, że wsparcie otrzymywane i spostrzegane w przypadku NI nie zawsze ze sobą korelują.

Sieć wsparcia społecznego jest bardzo istotna w spostrzeganiu jakości życia i w kreowaniu dobrego samopoczucia. Udzielane wsparcie, szczególnie przez osoby bliskie, pozwala NI uzyskać bardzo konkretną pomoc, emocjonalne wspar- 
cie, dostarczyć i pomóc w zrozumieniu ważnych informacji oraz stwarza szansę na poszerzanie kontaktów społecznych. Okazuje się, że wśród dorosłych NI aż 61\% uczestników programu treningowego nie posiadało przyjaciół (Katz, Yekutiel 1974, za: McVilly i in. 2006), natomiast ich bliskie kontakty miały dość specyficzny charakter ograniczający się do członków personelu instytucji lub/i innych NI w nich przebywających (tylko 36\% deklarowało brak przyjaciól) lub osób z najbliższej społeczności (58\%). Dorośli NI mieszkający w domach rodzinnych w $42 \%$ deklarowali brak bliskich osób poza najbliższą rodziną (Krauss i in. 1992, za: McVilly i in. 2006). Badania przeprowadzone przez McVilly'ego i in. (2006) wykazały, że poczucie osamotnienia w 19\% jest wyjaśniane przez rodzaj warunków nauczania i rodzaj aktywności w ciągu dnia (na podstawie współczynników regresji krokowej). Osoby, które uczyły się w szkołach specjalnych, czuły się bardziej samotne niż te, które pobierały naukę $w$ integracji. Praca $w$ warunkach chronionych wśród innych również stanowiła czynnik chroniący, chociaż nawet $w$ tej sytuacji kontakty ograniczały się głównie do miejsca pracy.

\section{Sposoby zapobiegania i niwelowania samotności}

Poważne konsekwencje coraz powszechniejszego odczuwania przez NI poczucia osamotnienia powinny skłaniać do poszukiwania sposobów udzielania pomocy osobom cierpiącym z tego powodu. Profesjonalne próby interwencji w odniesieniu do poczucia samotności były przeprowadzane bardzo rzadko. R.A. Bell i in. (1990, za: Dołega 2003) zauważyli, że wzrost liczby i częstości kontaktów z ludźmi redukuje poczucie samotności społecznej, ale nie ma wpływu na samotność emocjonalną.

P. Mason i in. (2013) zwracają uwagę na problem samotności osób NI sygnalizowany w rządowym dokumencie White Paper "Valuing People”, który podkreśla potrzebę takiego dostosowania usług $\mathrm{w}$ postaci informacji oraz wsparcia, aby osłabić tą izolację. Proponowane są różne rozwiązania angażujące profesjonalistów oraz lokalną społeczność oraz oddziaływania stymulujące i kompensujące deficyty umiejętności społecznych osób NI. Jedną z takich prób sprawdzenia efektywności udzielanej NI i osobom z zaburzeniami psychiatrycznymi pomocy w tym zakresie był program poprawiania "społecznego uczestnictwa” (social participation) realizowany w Holandii w ramach większego projektu: Opieka dla Poprawy (Care for Better). Celem tego projektu było poszerzenie sieci społecznego wsparcia tych osób celem przezwyciężenia poczucia osamotnienia. Zastosowano dwa podejścia: zindywidualizowane i znormalizowane. W podejściu indywidualnym skoncentrowano się na indywidualnych życzeniach NI, których zachęcano 
do werbalizowania tych potrzeb i bycia bardziej przedsiębiorczymi $w$ ich zaspokajaniu. Drugie podejście miało na celu zintegrowanie NI z lokalną społecznością. W realizację projektu zaangażowano 29 zespołów składających się z pięciu osób i pracujących przez rok z 20-30 osobami NI?. Okazało się, że wprawdzie obiektywnie nie zwiększyła się liczba kontaktów społecznych, ale obniżyło się poczucie osamotnienia badanych. Wybór metody poszerzania kontaktów zależał od preferencji uczestników programu i od sposobu jego realizacji. Indywidualne podejście sprzyjało także doskonaleniu się członków zespołu, co poprawiało jakościowo relacje z podopiecznymi. Część osób badanych o najniższych wskaźnikach poczucia osamotnienia zrezygnowała $\mathrm{z}$ udziału $\mathrm{w}$ drugim pomiarze (Broer i in. 2011). Również analizy K.R. McVilly' ego i in. (2006) potwierdzają, że małe społeczności sprzyjają budowania większej sieci wsparcia społecznego niż duże grupy.

Dzieci NI, radząc sobie z uczuciem osamotnienia, stosują zarówno strategie pozytywne aktywne (poszukiwanie kontaktu) konstruktywne, pasywne (wycofanie), jak i negatywne (agresja), co wydaje się być uwarunkowane także relacjami panującymi w rodzinach tych dzieci (Papoutsaki i in. 2013). H. Sullivan i D. Suttle (Rembowski 1992) analizując zachowania samotnych dzieci zwrócili uwagę na stosowanie przez nie mechanizmu obronnego polegającego na ucieczce w świat fantazji, który daje im kompensację w zakresie potrzeby intymności, czułości.

\section{Zakończenie}

Dokonany przegląd badań pozwala na sformułowanie kilku ogólnych wniosków dotyczących poczucia osamotnienia osób NI. Po pierwsze, warto podkreślić fakt, że tradycyjne sposoby zbierania danych za pomocą skal i kwestionariuszy skonstruowanych dla osób sprawnych intelektualnie okazują się być mało wiarygodne. Wymagają one modyfikacji polegających na stosowaniu wersji krótszych, z uproszczonym językiem, parafrazowania pytań, udzielania dodatkowych wyjaśnień, czytania itemów i udzielania pomocy przy ich wypełnianiu (Kościelak 1996; Stancliffe i in. 2014). W związku z tym bardziej użyteczne okazały się częściowo strukturalizowane wywiady (Lehman i in. 2013; Lunsky 2004; Manson in. 2013; McVilly $\mathrm{i}$ in.2006), nieformalne rozmowy w warunkach naturalnych (Broer i in. 2011) lub ankiety własnej konstrukcji (Kościelak 1996).

W badaniach, w których proszono o scharakteryzowanie odczuć związanych z poczuciem osamotnienia lub określeniem, na czym polega przyjaźń i jaką rolę pełni w łagodzeniu tych doznań, nie stwierdzono różnic jakościowych w odpowiedziach osób NI i pełnosprawnych intelektualnie (Kościelak 1996; Manson i in.2013). 


\begin{tabular}{|c|c|c|c|c|c|c|c|}
\hline 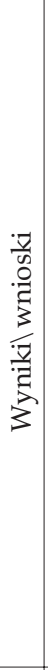 & 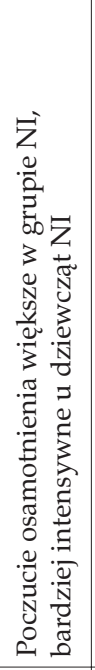 & 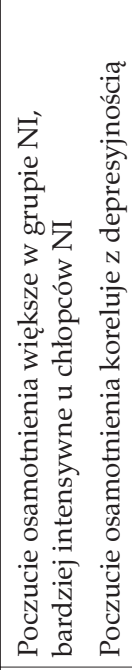 & 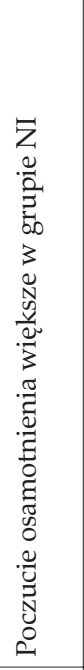 & 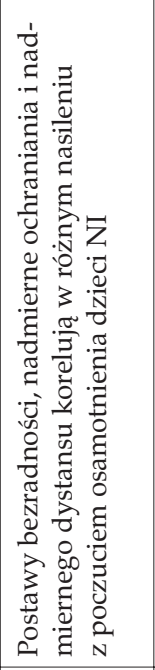 & 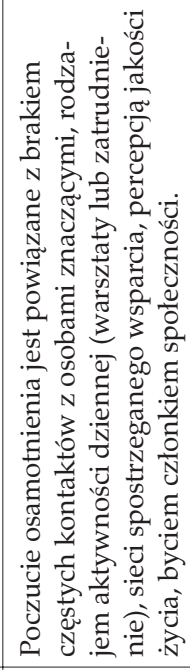 & 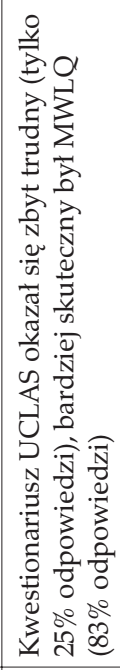 & 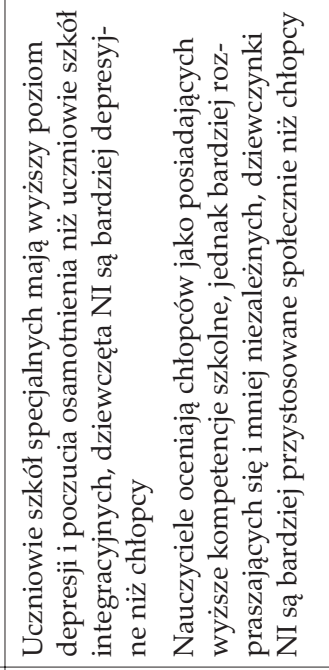 \\
\hline 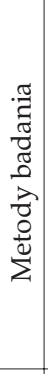 & 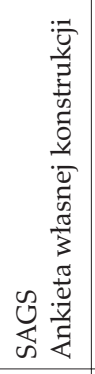 & 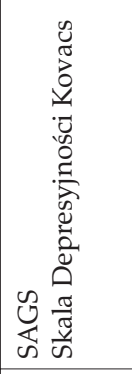 & 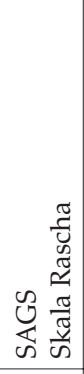 & 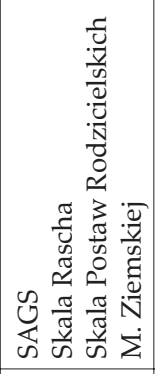 & 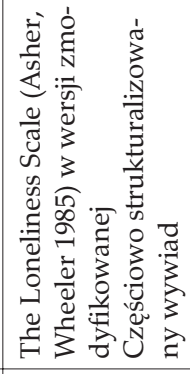 & 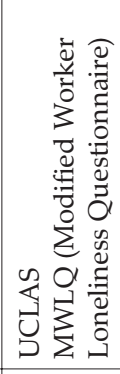 & 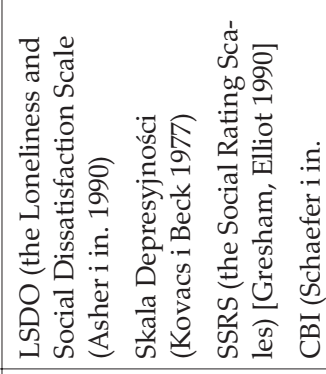 \\
\hline 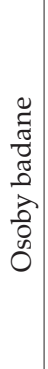 & 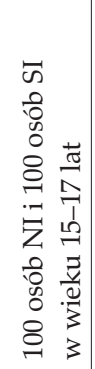 & 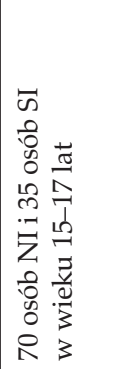 & 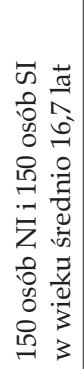 & 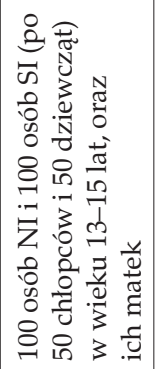 & 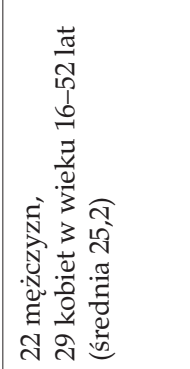 & 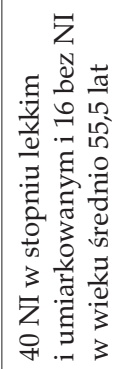 & 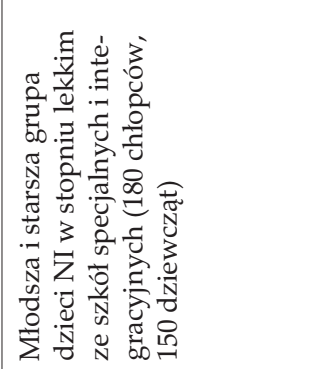 \\
\hline $\begin{array}{l}\frac{y}{a} \\
\stackrel{a}{a}\end{array}$ & よั & ఫ્ટે & $\stackrel{\infty}{\sigma}$ & ঙ্ণ & ఫి & ్ㅗㅇ & ఫ్రి \\
\hline 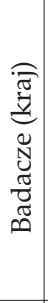 & 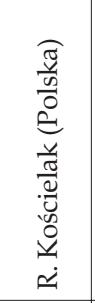 & 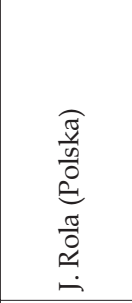 & 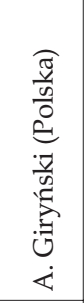 & 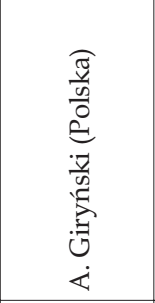 & 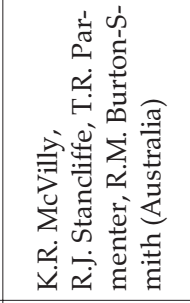 & 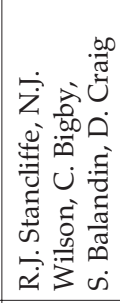 & 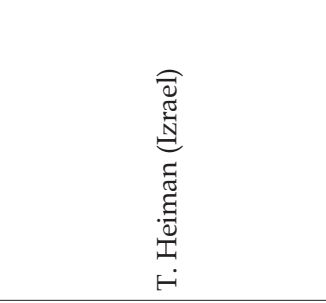 \\
\hline 工 & $-i$ & i & $\dot{\theta}$ & +i & in & $0^{\circ}$ & 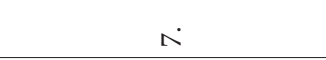 \\
\hline
\end{tabular}




\begin{tabular}{|c|c|c|c|}
\hline 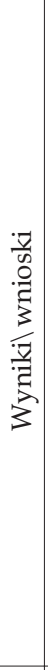 & 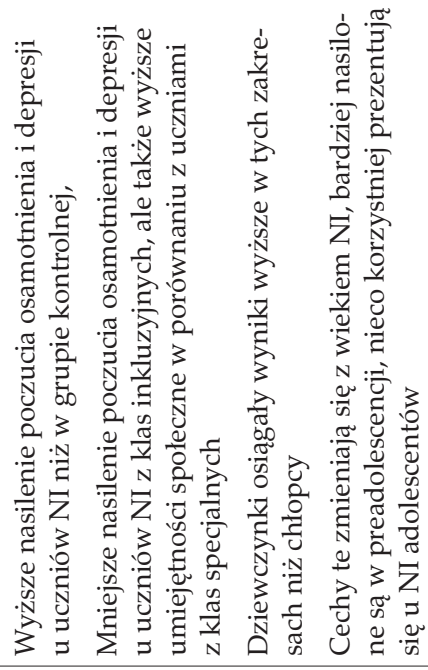 & 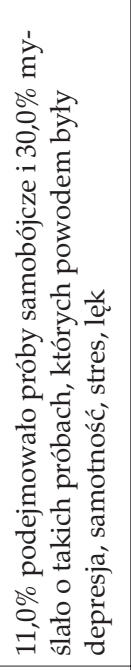 & 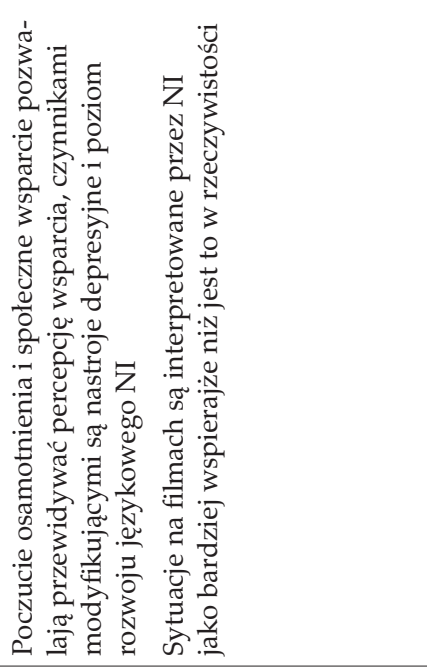 \\
\hline 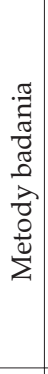 & 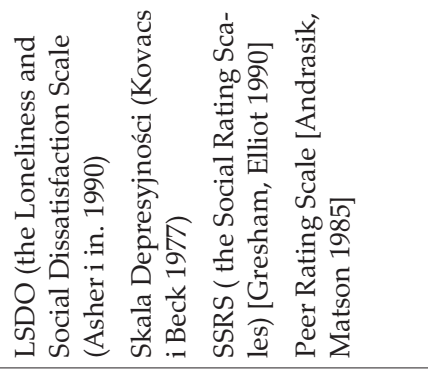 & 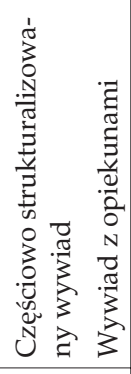 & 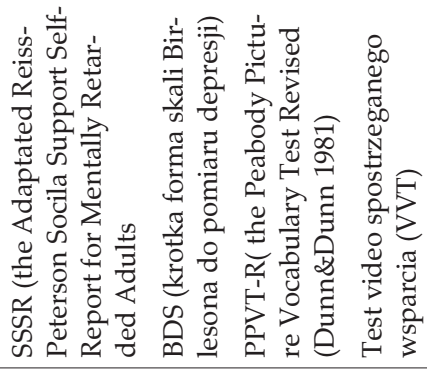 \\
\hline 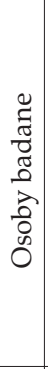 & 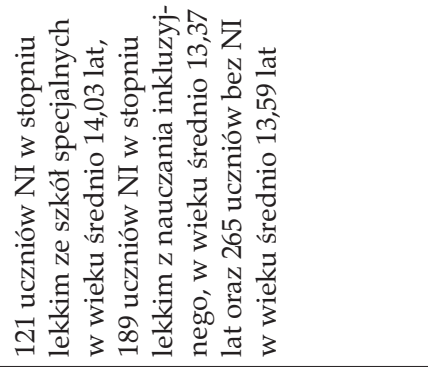 & 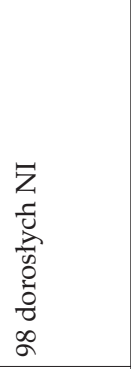 & 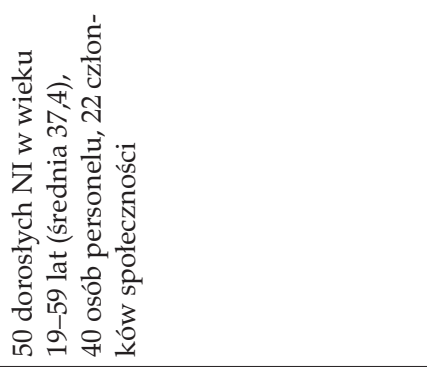 \\
\hline $\begin{array}{l}\ddot{y} \\
\stackrel{0}{a}\end{array}$ & ুొ & ষ্ণ & 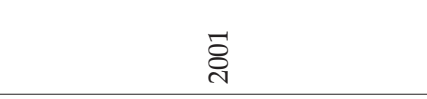 \\
\hline $\begin{array}{l}\overparen{\pi} \\
\tilde{\pi} \\
\tilde{J} \\
0 \\
\frac{\pi}{\pi} \\
\infty\end{array}$ & 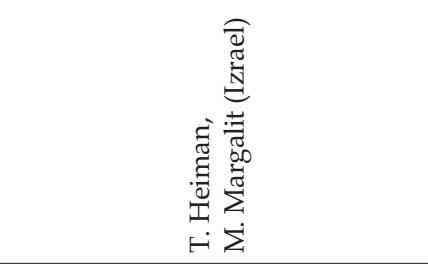 & 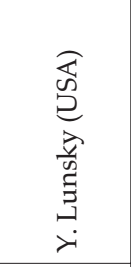 & 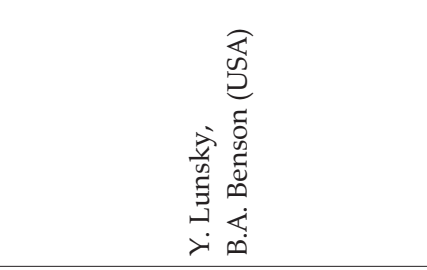 \\
\hline $\overrightarrow{3}$ & $\infty \infty^{\circ}$ & $\sigma^{\circ}$ & $\stackrel{?}{\circ}$ \\
\hline
\end{tabular}




\begin{tabular}{|c|c|c|c|c|}
\hline 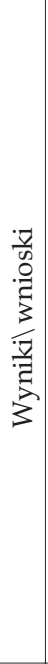 & 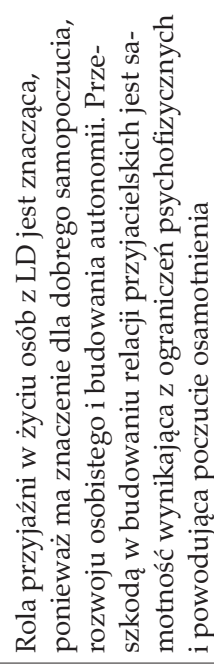 & 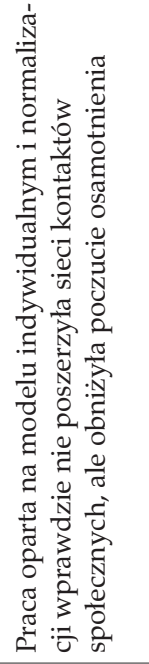 & 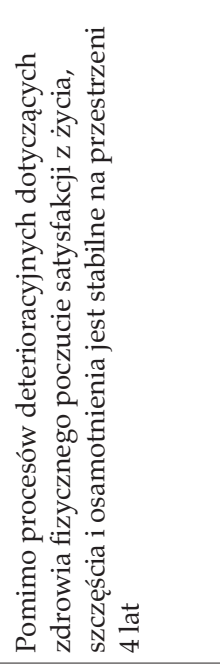 & 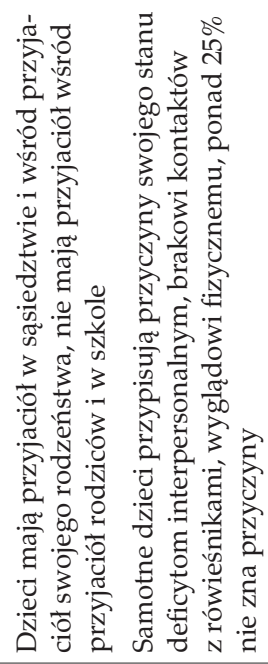 \\
\hline 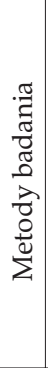 & 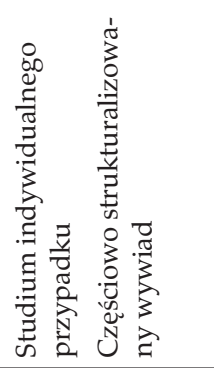 & 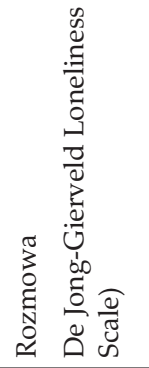 & 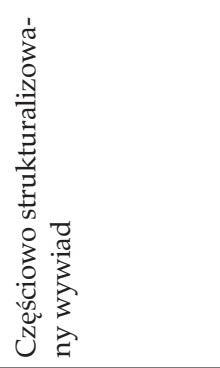 & 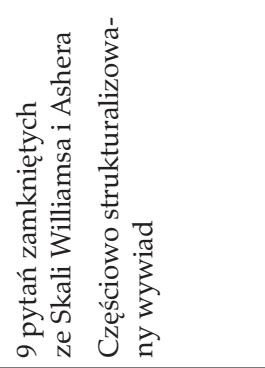 \\
\hline $\begin{array}{l}0 \\
\tilde{J} \\
\tilde{0} \\
0 \\
\overrightarrow{0} \\
0 \\
0 \\
0\end{array}$ & 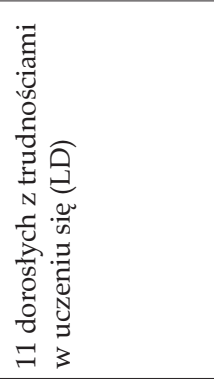 & 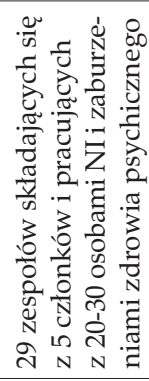 & 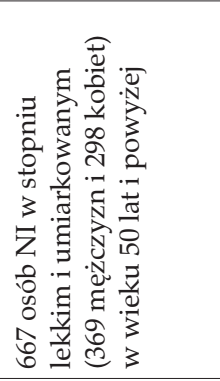 & 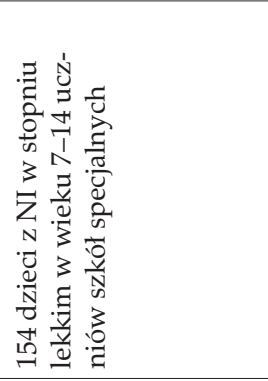 \\
\hline $\begin{array}{l}\frac{y}{a} \\
\simeq\end{array}$ & ఠి & $\overrightarrow{\widetilde{C}}$ & ิㅗ & $\stackrel{m}{3}$ \\
\hline 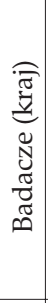 & 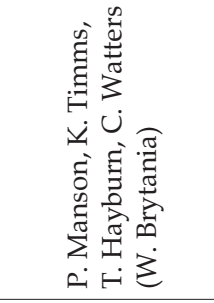 & 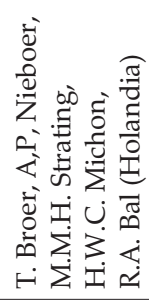 & 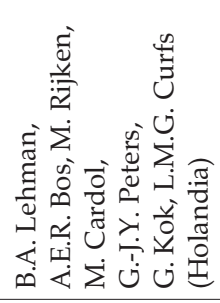 & 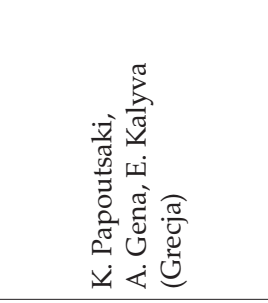 \\
\hline స & $\Xi$ & 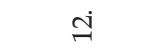 & 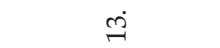 & $\underset{\sim}{\sim}$ \\
\hline
\end{tabular}


Praktycznie wszystkie badania potwierdziły większe nasilenie poczucia osamotnienia u osób NI niż u osób sprawnych intelektualnie. Wpływ zmiennej płci nie jest do końca jednoznaczny, być może należałoby zbadać interakcyjny wpływ płci i wieku. Wśród przyczyn podawanych przez samych NI i ich opiekunów były: ograniczone możliwości różnorodnych kontaktów społecznych, brak umiejętności inicjowania i podtrzymywania tych kontaktów oraz stygmatyzacja społeczna. Osoby NI częściej upatrują przyczyn swego osamotnienia w okolicznościach zewnętrznych, podczas gdy sprawni intelektualnie wiążą je raczej z cechami i decyzjami samego człowieka (Giryński 1998, 2004). Prawdopodobnie jest dużo racji w powyższym stwierdzeniu, ponieważ osoby NI ze względu na swoje cechy psychofizyczne często są izolowane społecznie i również ze strony osób sprawnych intelektualnie brakuje inicjatywy w budowaniu bliższych z nimi relacji. Uzasadnieniem tych niekorzystnych postaw społecznych jest spostrzeganie NI jako osób z wysokim poziomem lęku, impulsywnych, z niską samoocena, niską tolerancją na frustrację i deficytem umiejętności społecznych (Papoutsaki, Gena, Kalyva 2013). Pewne znaczenie dla poczucia osamotnienia NI okazują się mieć: postawy rodzicielskie (Giryński 1998), system edukacyjny (inkluzja versus ekskluzja) (Heiman 2001; Heiman, Margalit 1998), spostrzegane wsparcie społeczne i udział w lokalnej społeczności (Lunsky, Benson 2001).

Konsekwencją społecznej izolacji i odrzucenia osób NI i ich wysokiego poziomu osamotnienia mogą być zaburzenia zachowania, agresja, wrogość i niskie osiągnięcia szkolne (Papoutsaki i in. 2013); niska samoocena, bezradność (Rola 2004, 2005), zaburzenia struktury „ja” manifestujące się w postaci zachowań ryzykownych i/lub wycofywania się z kontaktów społecznych (Kościelak 1996). Najczęstszym korelatem poczucia osamotnienia osób NI była depresja lub depresyjność. Pomimo że obydwa zjawiska mogą rozwijać się niezależnie (Rook 1984), to jednak bardzo często współwystępują (Rembowski 1992). Badania J. Roli (2004, 2005), T. Heimana (2001), Lunsky (2004) wskazują, że poczuciu osamotnienia NI zazwyczaj towarzyszy podwyższony poziom depresyjności lub depresji.

Przedstawione w niniejszym opracowaniu wnioski skłaniają do stwierdzenia, że poczucie osamotnienia jest ważną zmienną pozwalającą prognozować powodzenie rehabilitacji społecznej NI. Warto skorzystać z już opracowanych rozwiązań, a także zastanowić się nad opracowaniem programów uwzględniających specyfikę polskich warunków.

\section{Bibliografia}

Albisetti V. (1999), Dobrodziejstwo samotności, Wydawnictwo Jedność, Kielce.

Broer T., Nieboer A.P., Strating M.M.H., Michon H.W.C., Bal R.A. (2011), Constructing the social: an evaluation study of the outcomes and processes of a 'social participation' improvement Project, "Journal of Psychiatric and Menthal Health Nursing", no. 18, s. 323-332. 
Dołęga Z. (2003), Samotność młodzieży-analiza teoretyczna i studia empiryczne, Wydawnictwo UŚ, Katowice.

Forts A.M., Luckasson R. (2011), Reading, Writting, and Frienship: Adult Implications of Effective Literacy Instruction for Students with Intellectual Disability, "Research \& Practice for Persons with Severe Disabilities", vol. 36, no. 3-4, s. 121-125.

Gajda J. (1997), Wartości w życiu człowieka. Prawda - mitość - samotność, Wydawnictwo UMCS, Lublin.

Giryński (1998), Poczucie samotności osób z upośledzeniem umysłowym a ich funkcjonowanie interpersonalne [w:] Tożsamość polskiej pedagogiki specjalnej u progu XXI wieku, red. J. Pańczyk, Wydawnictwo WSPS, Warszawa, s. 194-203.

Giryński A.(2004), Poczucie samotności dzieci niepetnosprawnych intelektualnie w zależności od postaw rodzicielskich, „Szkoła Specjalna”, nr 1, s. 3-17.

Heiman T. (2001), Depressive mood in students with mild intellectual disability: student's reports and teacher's evaluations, "Journal of Intellectual Disability Research", no. 45, s. 256-534.

Heiman T., Margalit M. (1998), Loneliness, Depression, and Social Skills among Students with Mild Mental Retardation in Different Educational Settings, "Journal of Special Education", vol. 32, no. 3, s. 154-163.

Kościelak R. (1996), Funkcjonowanie psychospołeczne a upośledzenie umysłowe, WSiP, Warszawa.

Lehmnan B.A., Bos A.E.R., Rijken M., Cardol M., Peters G.-J.Y., Kok G., Curfs L.M.G.. (2013), Ageing with an intellectual disability: the impact of personal resources on well - being, "Journal of Intellectual Disability Research", vol. 57, part 11, s. 1068-1078.

Lunsky Y. (2004), Suicidal in a clinical and community sample of adults with mental retardation, "Research in Developmental Disabilities”, vol. 25, s. 231-243.

Lunsky Y., Benson A. (2001), Perceived Social Support and Mental retardation: A Social-Cognitive Approach, "Cognitive Therapy and Research", vol. 25, no. 1, s. 77-90.

Łopatkowa (1983), Samotność dziecka, WSiP, Warszawa.

Mason P., Timms K., Hayburn T., Watters C. (2013), How do people described as having a Learning Disability Make sense of friendship?, "Journal of Applied Research in Intellectual Disabilities", no. 26, s. 108-118.

McVilly K.R., Stancliffe R.J., Parmenter T.R., Burton-Smith R.M. (2006), "I Get by with a Little Help from my Friends": Adult with Intellectual Disability Discuss Loneliness, ,Journal of Applied Research in Intellectual Disabilities", no. 19, s. 191-203.

Papoutsaki K., Gena A., Kalyva E. (2013), How do Children with Mild Intellectual Disabilitiea Perceive Loneliness?, „Europe's Journal of Psychology”, nr 9(1), s. 51-61.

Rembowski J. (1992), Samotność, UG, Gdańsk.

Reisman D., Glazer N., Denney R. (1996), Samotny ttum, Muza, Warszawa.

Rola J. (2004), Melancholia rodzinna. Psychologiczne uwarunkowania zaburzeń depresyjnych dzieci z niepetnosprawnościa Intelektualna, Wydawnictwo APS, Warszawa.

Rola J. (2005), Poczucie osamotnienia a depresja dziecka z niepetnosprawnościa intelektualna [w:] Edukacja - socjalizacja - autonomia w życiu osoby niepetnosprawnej, red. A. Klinik, J. Rottermund, Z. Gajdzica, Oficyna Wydawnicza „Impuls”, Kraków, s. 137-146.

Rook K.S. (1984), Research on Social Support, Loneliness and Social Isolation, „Review of Personality and Social Psychology", no 5, s. 240-264. 
Sharabi A., Levi U., Margalit M. (2012), Children's Loneliness, Sense of Coherence, Family Climate, and hope: Developmental Risk and Protective Factors, "The Journal of Psychology", vol. 146(1-2), s. 61-83.

Stancliffe R.J., Wilson N.J., Bigby C., Balandin S., Craig D. (2014), Responsiveness to self report questions about loneliness: a comparison of mainstream and intellectual disability- specific instruments, "Journal of Intellectual Disability Research", vol. 58, part 5, s. 399-405.

Szczupał B. (2005), Poczucie samotności dziecka przewlekle chorego jako problem pedagogiczny [w:] Edukacja - socjalizacja - autonomia w życiu osoby niepetnosprawnej, red. A. Klinik, J. Rottermund, Z. Gajdzica, Oficyna Wydawnicza „Impuls”, Kraków, s. 109-118.

Wasilewska K.M. (2010), Samotność młodzieży, Wydawnictwo Kujawsko-Pomorskiej Szkoły Wyższej w Bydgoszczy, Bydgoszcz. 